\title{
Tissue harmonic imaging in comparison with conventional sonography: Effect on image quality of the nuchal translucency measurement
}

\author{
Doku harmonik görüntüleme ile konvansiyonel ultrasonografinin \\ karşılaştırılması: Ense kalınlı̆̆ı ölçümünde görüntü kalitesi üzerine etkisi \\ Işın Ceylan*, Ali Er \\ Department of Radiology (I. Ceylan, MD), Kartal Kızılay Medical Center, TR-34860 İstanbul, \\ Department of Radiology (A. Er, MD), Kanuni Sultan Süleyman Education and Research \\ Hospital, TR-34303 İstanbul
}

\begin{abstract}
Aim. In this study, tissue harmonic imaging (THI) was compared with conventional gray scale ultrasonography (CUS) by scoring system in measurement of nuchal translucency (NT) and in examination of fetal posterior neck region. Additionally, it was also investigated that whether body habitus of patient provide effect on this condition or not. Methods. Fetal neck region and nuchal translucency were evaluated by using scoring system (1: not seen, 2 : seen uncertainly, 3 : seen acceptably, 4: well seen, and 5: very well seen). The tissue harmonic imaging was compared with B-mode. Results. In normal patients, overall average score (11+0 to $13+6$ weeks) for CUS was 3.27 and it was 3.69 for THI. However, in obese patients, overall average score for CUS was 2.96 and it was 3.48 for THI. For the group with normal BMI; examination with tissue harmonic imaging was on average more clearly visible in $44.6 \%$ of the cases, the same as in the conventional B-mode in $53 \%$, and worse in only $2.4 \%$. However, in obese group; examination with tissue harmonic imaging was on average more clearly visible in $51.2 \%$ of the cases, the same as in the conventional B-mode in $46.4 \%$, and worse in only $2.4 \%$. Conclusion. When normal group and obese groups are completely considered, it was found that THI provides similar or better image quality almost in all of the patients than that of CUS.
\end{abstract}

Keywords: Harmonic imaging, scoring system, ultrasonography, body mass index

\section{Özet}

Amaç. Bu çalışmada, fetus boyun posterior bölgesinin değerlendirilmesinde ense kalınlığı ölçümü doku harmonik görüntüleme (DHG) ve konvansiyonel gri skala ultrasonografide (KUS) skorlama sistemi ile karşılaştırılmıştır. Ayrıca hastaların vücut habitusunun ölçümlere etkisinin olup olmadığ araştırılmıştır. Yöntem. Fetal boyun bölgesi ve ense kalınlığı skorlama sistemi kullanılarak değerlendirildi (1: görülemeyen, 2: belirsiz görülen, 3: kabul edilebilir ölçüde görülen, 4: iyi görülen, 5: çok iyi görülen). Doku harmonik görüntüleme B mod ultrasonografi ile karşılaştırıld. Bulgular. Normal hastalarda, genel ortalama puan (11+0 ile 13+6 hafta) KUS'de 3,27 ve DHG ile 3,69 idi. Ancak, obez hastalarda genel ortalama puan KUS' de 2,96 ve DHG ile 3,48 idi. Normal vücut kitle indeksi olan grupta; DHG ile değerlendirmede ortalama olarak çok net görülebilen grup hastaların \%44,6'sı, KUS ile hastaların \%53'üdür. Sadece $\% 2,4$ görüntü kötü sınıfında idi. Ancak obez grupta; DHG ile ortalama olarak çok net görülebilen grup hastaların \% 51,2' si, KUS ile hastaların \%46,4' ü dür. Sadece \%2,4 görüntü kötü sınıfında idi. Sonuç. Normal grup ve obez grup tümüyle ele alındığında; tüm hastalarda DHG, KUS ile benzer yada daha iyi görüntü kalitesi sağlamaktadır.

Anahtar sözcükler: Harmonik görüntüleme, skorlama sistemi, ultrasonografi, vücut kitle indeksi

Geliş tarihi/Received: February 21, 2013; Kabul tarihi/Accepted: February 28, 2014

*Corresponding author:

Dr. Işın Ceylan, Radyoloji Bölümü, Kartal Kızılay Tıp Merkezi, TR-34860 İstanbul. E-mail: isin.ceylan@hotmail.com 


\section{Introduction}

In pregnancy; various sonographic markers such as the nuchal translucency (NT) became important as the early screening method for chromosomal abnormality [1, 2]. Obtaining an accurate measurement of NT by ultrasonography is an essential and critical component of screening which has significant implications in clinical practice. There are many studies on its contribution to NT measurement and detection of various abnormalities [35]. Moreover, there are many studies demonstrating superior image quality of Tissue harmonic imaging (THI) in comparison with conventional grey-scale ultrasonography (CUS) and also demonstrating image quality in examining various tissues [6-8].

In our study, whilen conventional grey-scale ultrasonography (CUS) is used for obstetric examination and Tissue harmonic imaging ultrasonography (THI) was used in NT measurement conducted simultaneously, we aimed to investigate whether THI examination and NT measurement cause a significant difference among them. Additionally, as various studies demonstrated that THI provided better image quality in obese patients $[9,10]$. We also aimed to investigate whether it provides any contribution to examination of fetal posterior neck region in obese patients.

\section{Materials and methods}

Our study was conducted with patients referred to radiology department of our hospital for obstetric examination. Appropriate patients, with gestation weeks of 11-14 weeks due to calender estimates, were indiscriminately enrolled to the study by conducting required measurements defined below.

Two groups were established by patients and this classification was conducted in accordance with body mass index (BMI). First group was pregnant women with BMI 18.5 to 24.9 (control group) (optimal weight) and second one is pregnant women with BMI > 30 (group of obese women). First group was consisted of 83 patients and second groups was consisted of 41 patients. BMI $\left(\mathrm{kg} / \mathrm{m}^{2}\right)$ of all patients were estimated with body weight $(\mathrm{kg})$ and height $(\mathrm{m})$ measurements of patients. Radiology specialist conducting the ultrasonography was blind to the BMI values of patients. Examinations of fetal posterior neck region and NT measurements were conducted in pregnant between gestational age of 11-14 weeks. Gestational age, that was calculated from the first day of the last menstrual period and was confirmed by crown-rump length (CRL) measurement. When there is difference over than 7 days according to the menstrual calculations, gestational age of the patient was validated as ultrasonographic estimate.

Examination of fetal posterior neck region and NT measurement was conducted transabdominally. Following NT measurement criteria were followed during examination and examination. Upon meeting these criteria, scoring and NT measurement processes were conducted. In scoring, internal and external border clarities were taken into consideration. For scoring, Definition of score criteria were used and only one point was assigned in examination (between 1 and 5 points). During measurement, crossbar echolusent space in inner borders were localized and measurement were conducted by maximizing images for correct measurements (fetal image occupies at least $75 \%$ of the ultrasound screen) (Figure $1)$.

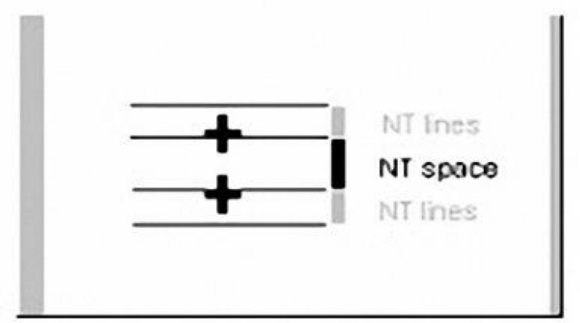

Figure 1. NT measurement. The calipers should be placed on the inner borders of the NT lines. Horizontal crossbars should not extend to NT space (black space on ultrasound). 
When hesitated between fetal skin and amniotic membran during examination, fetal position change was required for correct measurement. For this, spontaneous movement of fetus was awaited. When fetus was not spontaneously moved, mother was asked to cough or abdomen of the mother was tapped. Cine-loop function of the device was used in selecting appropriate and satisfactory position of the fetus.

All measurements were performed using a CDI set: Logiq S6 (GE Medical System, Milwaukee, Wisconsin, USA) using a $2-5-\mathrm{MHz}$ convex transducer. All examinations were conducted by the same radiologist. Among the patients enrolled to the study, none of them had history of pre-pregnancy systemic disease. None of the patients had continous medication. Due to the results, intra- and inter-group comprisons were made.

\section{Statistical analyses}

In comparison of average scores obtained from fetal posterior neck examination and NT measurement in both intra-group comparisons in terms of conventional grey-scale imaging and tissue harmonic imaging and also in comparison of CUS results and THI results, Independet Samples $\mathrm{T}$ test was used. Statistical analysis was performed by Statistics Package for Social Science (SPSS) 13.0 computer software. A $p$ value of $<0.05$ was considered statistically significant. Data are presented as mean \pm SD.

\section{NT measurement criterias:}

1. NT measurements and examinations were conducted by same individual.

2. Gestational age between 10 weeks and 13 weeks 6 days.

3. Fetus in a mid-sagittal plane.

4. Fetal image occupies at least $75 \%$ of the ultrasound screen.

5. Distinguish between the amnion and overlying fetal skin.

6. Fetal neck in the neutral position (fetal head in the neutral position)

7. Calipers placed perpendicular to the long axis of the fetal body and calipers placed on the inner border of the nuchal fold (horizontal crossbars).

\section{Definition of scores}

1. Not seen; not even suggestive of a structure.

2. Seen uncertainly; suggestive of a structure, but structure cannot be clearly seen.

3. Seen acceptably; structure can be clearly seen.

4. Well seen; structure can be clearly seen.

5. Very well seen; structure can be very clearly seen, no better visualization possible.

\section{Results}

In normal group consisted of 83 individuals, mean BMI values were 22.14 \pm 1.62 (SD), and it was $30.93 \pm 0.9$ (SD) in obese group consiting of 41 individuals.

Mean gestational age was $22.7 \pm 3.24$ (SD) (range: 18-31) in normal group and $26.2 \pm 2.8$ (SD) (range: 20-32) in obese group.

General mean score $(11+0$ to $13+6$ weeks) in normal patients were 3.27 for CUS (In order from high to low: 12.0-12.6 weeks: 3.45, 13.0-13.6 weeks: 3.22, 11.0-11.6 weeks: 3.16). General mean score $(11+0$ to $13+6$ weeks) in normal patients were 3.69 for THI (In order from high to low: 12.0-12.6 weeks: 3.90, 13.0-13.6 weeks: 3.66, 11.0-11.6 weeks: 3.52 ) (Table 1).

General mean score $(11+0$ to $13+6$ weeks) in obese group was 2.96 for CUS (In order from high to low: 12.0-12.6 weeks: 3.06, 11.0-11.6 weeks: 3.0, 13.0-13.6 weeks: 2.96). 
General mean score $(11+0$ to $13+6$ weeks) in obese patients was 3.48 for THI (In order from high to low: 12.0-12.6 weeks: 3.60, 11.0-11.6 weeks: 3.46, 13.0-13.6 weeks: 3.38) (Table 2).

Mean NT thickness measured by CUS in patients with normal BMI: $1.36 \mathrm{~mm}$, and also mean NT thickenss by THI: $1.37 \mathrm{~mm}$. Mean NT thickness in obese patients with CUS and THI: 1,5 $\mathrm{mm}$ (Table 1 and 2).

Table 1. The distribution of nuchal translucency (NT) measurement in normal fetuses based on gestational age (Convensiyonal and Tissue Harmonic US) (group of normal women).

\begin{tabular}{|c|c|c|c|c|c|c|c|}
\hline \multirow{4}{*}{$\begin{array}{l}\text { Gestational age } \\
\text { (weeks) }\end{array}$} & \multirow{4}{*}{$\mathbf{N}$} & \multicolumn{6}{|c|}{ Ultrasonographic measurement } \\
\hline & & \multicolumn{3}{|c|}{ Convensiyonal US } & \multicolumn{3}{|c|}{ Tissue Harmonic US } \\
\hline & & \multirow{2}{*}{$\begin{array}{c}\text { CRL (mm) (mean / } \\
\text { std) }\end{array}$} & \multicolumn{2}{|c|}{ NT (mm) } & \multirow{2}{*}{$\begin{array}{c}\text { CRL (mm) (mean } \\
\text { / std) }\end{array}$} & \multicolumn{2}{|c|}{ NT (mm) } \\
\hline & & & $\begin{array}{c}\text { Meas (mean } \\
\text { /std) }\end{array}$ & $\begin{array}{c}\begin{array}{c}\text { Score } \\
(\mathrm{mean} / \mathrm{std})\end{array} \\
\end{array}$ & & $\begin{array}{c}\text { Meas (mean } \\
\text { /std) }\end{array}$ & $\begin{array}{l}\text { Score (mean } \\
\text { /std) }\end{array}$ \\
\hline $11.0-11.6$ & 25 & $48.9 \pm 3.1$ & $1.25 \pm 0.15$ & $3.16 \pm 0.60$ & $48.3 \pm 3.1$ & $1.25 \pm 0.15$ & $3.52 \pm 0.64$ \\
\hline $12.0-12.6$ & 31 & $59.4 \pm 3.5$ & $1.36 \pm 0.17$ & $3.45 \pm 0.66$ & $59.4 \pm 3.1$ & $1.38 \pm 0.17$ & $3.90 \pm 0.65$ \\
\hline $13.0-13.6$ & 27 & $71.4 \pm 3.4$ & $1.49 \pm 0.20$ & $3.22 \pm 0.44$ & $71.4 \pm 3.4$ & $1.48 \pm 0.20$ & $3.66 \pm 0.55$ \\
\hline $\begin{array}{l}\text { Average mean } \\
\text { (score) }\end{array}$ & & & $1.36 \pm 0.19$ & $3.27 \pm 0.57$ & & $1.37 \pm 0.19$ & $3.69 \pm 0.63$ \\
\hline \multicolumn{8}{|c|}{ Score 1: not seen, 2: seen uncertainly, 3: seen acceptably, 4: well seen; and 5: very well seen. } \\
\hline C & & & & & & & \\
\hline
\end{tabular}

Table 2. The distribution of nuchal translucency (NT) measurement in normal fetuses based on gestational age (Convensiyonal and Tissue Harmonic US) (group of obese women).

\begin{tabular}{|c|c|c|c|c|c|c|c|}
\hline \multicolumn{2}{|c|}{ Subjects } & \multicolumn{6}{|c|}{ Ultrasonographic measurement } \\
\hline \multirow{3}{*}{$\begin{array}{l}\text { Gestational age } \\
\text { (weeks) }\end{array}$} & \multirow{3}{*}{$\mathbf{N}$} & \multicolumn{3}{|c|}{ Convensiyonal US } & \multicolumn{3}{|c|}{ Tissue Harmonic US } \\
\hline & & \multirow[b]{2}{*}{$\begin{array}{l}\text { CRL (mm) } \\
(\text { mean/std) }\end{array}$} & \multicolumn{2}{|c|}{ NT (mm) } & \multirow{2}{*}{$\begin{array}{l}\text { CRL(mm) } \\
\text { (mean/std) }\end{array}$} & \multicolumn{2}{|c|}{ NT (mm) } \\
\hline & & & $\begin{array}{c}\text { Meas } \\
\text { (mean/std) }\end{array}$ & $\begin{array}{c}\text { Score } \\
(\text { mean } / \text { std })\end{array}$ & & $\begin{array}{c}\text { Meas } \\
\text { (mean/std) }\end{array}$ & $\begin{array}{c}\text { Score } \\
(\mathrm{mean} / \mathrm{std})\end{array}$ \\
\hline $11.0-11.6$ & 13 & $47.5 \pm 3.1$ & $1.19 \pm 0.15$ & $3.00 \pm 0.60$ & $47.5 \pm 3.1$ & $1.18 \pm 0.15$ & $3.46 \pm 0.64$ \\
\hline $12.0-12.6$ & 15 & $59.8 \pm 3.5$ & $1.39 \pm 0.17$ & $3.06 \pm 0.63$ & $59.8 \pm 3.5$ & $1.40 \pm 0.17$ & $3.60 \pm 0.65$ \\
\hline $13.0-13.6$ & 13 & $72.3 \pm 3.4$ & $1.49 \pm 0.20$ & $2.84 \pm 0.59$ & $72.3 \pm 3.4$ & $1.47 \pm 0.20$ & $3.38 \pm 0.55$ \\
\hline Average mean (score) & & & $1.35 \pm 0.22$ & $2.96 \pm 0.57$ & & $1.35 \pm 0.23$ & $3.48 \pm 0.59$ \\
\hline \multicolumn{8}{|c|}{ Score 1: not seen, 2: seen uncertainly, 3: seen acceptably, 4: well seen; and 5: very well seen. } \\
\hline & & & & & & & \\
\hline
\end{tabular}

With respect to the examination results, for the group with normal BMI; NT examination with tissue harmonic imaging was on average more clearly visible in $44.6 \%$ of the cases, the same as in the conventional B-mode in $53 \%$, and worse in only $2.4 \%$. With respect to the examination results, for the obese group; NT examination with tissue harmonic imaging was on average more clearly visible in $51.2 \%$ of the cases, the same as in the conventional B-mode in $46.4 \%$, and worse in only $2.4 \%$. Nearly in all cases, tissue harmonic imaging was better or same when compared with the plain B-mode (Table 3).

Tablo 3. Tissue harmonic imaging compared with the B-mode ultrasonography.

\begin{tabular}{lllllll}
\hline & \multicolumn{3}{c}{ Normal (THI and B-mode) } & \multicolumn{3}{c}{ Obez (THI and B-mode) } \\
\cline { 2 - 7 } Gestational age (weeks) & Better & Same & Worse & Better & Same & Worse \\
\hline $11.0-11.6$ & 9 & 16 & - & 6 & 7 & - \\
$12.0-12.6$ & 16 & 14 & 1 & 9 & 5 & 1 \\
$13.0-13.6$ & 12 & 14 & 1 & 6 & 7 & - \\
\hline Total & $37(44.6 \%)$ & $44(53 \%)$ & $2(2.4 \%)$ & $21(51.2 \%)$ & $19(46.4 \%)$ & $1(2.4 \%)$ \\
\hline
\end{tabular}

For the group with normal BMI, there was a statistically significant difference between fetal neck region examination conducted by CUS and THI and mean scores obtained by NT measurement $(11+0$ to $13+6$ weeks $)(P=0,049)$. In a similar way, for the group consisted of obese individuals, there was a statistically significant difference between fetal neck region examination conducted by CUS and THI and mean scores obtained by NT measurement $(11+0$ to $13+6$ weeks $)(P=0,049)$.

There was also a significant increase when mean scores obtained by fetal neck region examination via CUS and NT measurement in group with normal BMI was compared 
with mean scores obtained by fetal neck region examination via CUS and NT measurement in obese group $(P=0,049)$. However, there was no significant decrease when mean scores obtained by fetal neck region examination via THI and NT measurement in group with normal BMI was compared with mean scores obtained by fetal neck region examination via THI and NT measurement in obese group $(P=0,127)$.

\section{Discussion}

First publications on association of NT abnormalities and fetal malformation were started by Benacerraf et al. [1] in 1988 who reported relation of Down's syndrome and nuchal fold, and later, studies on this topic were continued [11]. Nuchal translucency (NT) measurement is conducted in fetal posterior neck region between 11-14 weeks of gestation $[5,12]$. It was reported that measurements obtained within this period provides most accurate results, and that this is resulted from body habitus of patient and fetal position [13]. Examination of fetal neck region and NT measurements are now conducted by transabdominal and transvaginal US. NT measurement, conducted during transabdominal US, is commonly used due to its practice and it also provides highly accurate results [14].

Tissue harmonic imaging (THI) is relatively new technique against conventional sonography and it potentially provides better image quality [15]. Now, THI is widely used and the studies conducted on various organs such as breast $[16,17]$, thyroid gland [7], liver [8], gallbladder [6], carotid arteries [7], bile duct [18]. Additionally, there is no difficulty of use as it can be easily activated by pushing single button and it can be easily used in obstetric examination. This technique provides marked improvement of image quality in abdominal and pelvic studies of difficult to image (especially obese) patients $[9,10]$. Uterine fibroids are better imaged in pelvic examination. It is possible to examine better and identify fetal anatomy and placental structures in obstetric patients [19]. In our study, we concluded that THI increases image quality in comparison with CUS in examination of fetal posterior neck region and NT measurements both in normal and obese group and that it provided contribution to examination (Figure 2, Figure 3a-b).

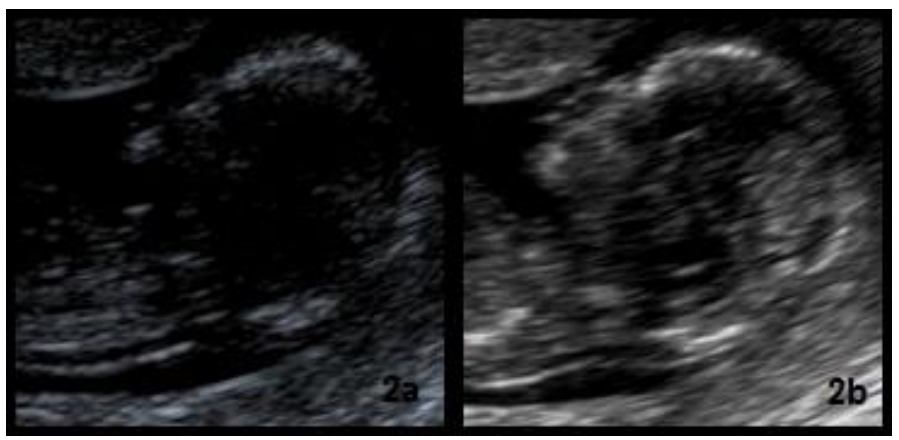

Figure 2. Fetus at $12+5$ weeks using the B-mode (a) compared with tissue harmonic imaging (b), demonstrating better visibility using tissue harmonic imaging in normal group.

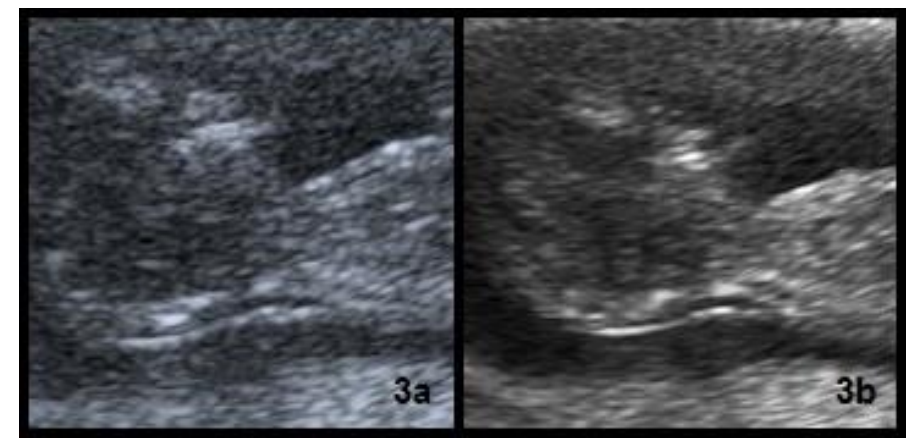

Figure 3. Fetus at 12+1 weeks using the B-mode (a) compared with tissue harmonic imaging (b), demonstrating better visibility using tissue harmonic imaging in obese group. 
As advantages of THI and conditions increasing image quality; THI images have improved the signal-noise ratio, narrowing of the width of the ultrasound beam, have reduced side lobe and reverberation artifacts, and have improved lateral resolution [16, $20,21]$.

Subcutaneous oedema in posterior fetal neck can be visualized as increase in nuchal translucency thickness in US examination (10-14 weeks of gestation) [3]. The more fluid that has accumulated, the greater the risk of an abnormality being present. Among them, there is also fluid accumulation in Down's syndrome and NT measurement provides significant benefit to us [22]. Moreover, congenital abnormalities of the heart and great arteries are associated with subcutaneous oedema in the neck region and it was reported that prevalence of major defects of the heart and great arteries increased by increase of NT thickness [3]. Additionally, though chromosome studies provide normal results, presence of increase in NT thickness revals the necessity to take increase in incidence of other fetal malformations into account. These malformations include skeletal anomalies, diaphragmatic hernia, and especially congenital cardiac disease [23].

There are many theories put forth to explain increase in nuchal translucency (abnormal fluid collections). Several of them are presence of cardiac failure or cardiac dysfunction in fetus, abnormal lymphatic vessels in neck region and failure of fetal movements $[13,20]$. Small changes in result obtained by NT measurements imply significant effects in risk examination of future anomaly scannings. Consequently, it is necessary and important to conduct measurement as accurately as possible [24]. Then, we investigated whether sonographic technique and body habitus of patients has an effect on examination of fetal posterior neck region and NT measurement. Hann LE et al. [8], determined the reason of suboptimal sonographic examinations as obesity, but they could not find any correlations in their study between improved image quality by THI and body mass index. Rosenthal SJ et al. [11], reported that THI determines normal kidneys, pancreas and aorta beter especially in obese patient and that fetal anatomy and placental structure are better imaged and uterine fibroids are clearly identified. They determined that it provides significant contribution in imaging renal and hepatic masses, gallstones, subtle hydronephrosis, appendicitis, and deep abdominal and pelvic fluid collections, again in obese patients. In their study, Von Kaisenberg CS et al. [25] reported that THI provided contribution to fetal visualization, but that there was no clear correlation between fetal visualization and BMI. In the study, Von Kaisenberg CS et al. [25], also examined the interobserver variability and reported that observers had identical results for 12 different anatomic region including fetal neck. In our study, we also obtained results suggesting that THI provides better image quality both in obese and normal patients in comparison with CUS in terms of fetal posterior neck evaluation and NT measurement. However, when we compared its contribution to examination of normal patients and obese patients, we could not obtained a significant difference. Pasquini et al. [26] reported that THI signal is weaker than that of CUS and during the scan this could lead to operatör increasing the gain. The increase in the gain could determine an additional underestimation of NT measurement. Fort his reason THI is an important too, in obstetric ultrasound, especially in technically difficult patients, for example obese pregnant women, in whom THI allows better visualization. In our study, when obese and normal groups are totaly considered, it was observed that THI provided identical or better image quality in almost all patients and additionally image quality was slightly lower than that of CUS.

As a result, we conclude that use of Tissue harmonic imaging in examination of fetal neck region during fetal ultrasonographic assessment will be beneficial in comparison with the images obtained by CUS due to better image quality of THI. 


\section{References}

1. Benacerraf BR, Neuberg D, Bromley B, Frigoletto FD Jr. Sonographic scoring index for prenatal detection of chromosomal abnormalities. J Ultrasound Med 1992; 11: 449-58.

2. Nicolaides KH, Azar G, Byrne D, Mansur C, Marks K. Fetal nuchal translucency: Ultrasound screening for chromosomal defects in first trimester of pregnancy. BMJ 1992; 304: 867-9.

3. Hyett J, Perdu M, Sharland G, Snijders R, Nicolaides KH. Using fetal nuchal translucency to screen for major congenital cardiac defects at 10-14 weeks of gestation: population based cohort study. BMJ 1999; 318; 81-5.

4. Chitty LS, Kagan KO, Molina FS, Waters JJ, Nicolaides KH. Fetal nuchal translucency scan and early abnormalities by rapid aneuploidy screening: prenatal diagnosis of chromosomal observational study. BMJ 2006; 332; 452-5.

5. Kim MH, Park SH, Cho HY, Choi JS, Kim JO, Ahn HK. Threshold of Nuchal Translucency for the Detection of Chromosomal Aberration: Comparison of Different Cut-offs. J Korean Med Sci 2006; 21: 11-4.

6. Hong HS, Han JK, Kim YH, Kim JS, Kim TK, Cha JH. Ultrasonographic Evaluation of the Gallbladder Comparison of Fundamental, Tissue Harmonic and Pulse Inversion Harmonic Imaging. J Ultrasound Med 2001; 20: 35-41.

7. Szopinski KT, Wysocki M, Pajk AM, Slapa RZ, Jakubowski W, Szopinska M. Tissue Harmonic Imaging of Thyroid Nodules Initial Experience. J Ultrasound Med 2003; 22: 5-12.

8. Hann LE, Bach AM, Cramer LO, Siegel D, Yoo HH, Garcia R. Hepatic Sonography: Comparison of Tissue Harmonic and Standard Sonography Techniques. AJR1999; 173: 201-6.

9. Desser TS, Jeffrey RB Jr, Lane MJ, Ralls PW. Tissue harmonic imaging: utility in abdominal and pelvic sonography. J Clin Ultrasound 1999; 27: 135-41.

10. Treadwell MC, Seubert DE, Zador I, Goyert GL, Wolfe HM. Benefits associated with harmonic tissue imaging in the obstetric patient. Am J Obstet Gynecol. 2000; 182: 1620-2.

11. Allan LD. The mystery of nuchal translucency. Cardiol Young 2006; 16: 11-7.

12. Malone FD, Canick JA, Ball RH, et al: First-trimester or second-trimester screening, or both, for Down's syndrome. N Engl J Med 2005; 353: 2001-11.

13. D'Alton ME, Malone FD, Messerlian G. Maintaining quality review for NT sonography in a prospective multicenter study: results from the FASTER trial. Am J Obstet Gynecol 2003; 189: 78.

14. Abuhamad A. Technical Aspects of Nuchal Translucency Measurement. Semin Perinatol 2005; 29: 376-9.

15. Shapiro RS, Wagreich J, Parsons RB, Pasik AS, Yeh HC, Lao R. Tissue Harmonic Imaging Sonography: Evaluationof Image Quality Compared with Conventional Sonograph. AJR 1998; 111: 1203-6.

16. Rosen EL, Soo MS. Tissue harmonic imaging sonography of breast lesions: improved margin analysis, conspicuity, and image quality compared to conventional ultrasound. Clin Imaging 2001; 25: 379-84.

17. Seo BK, Oh YW, Kim HR. Sonographic evaluation of breast nodules: comparison of conventional, real-time compound, and pulse-inversion harmonic images. Korean J Radiol 2002; 3: 38-44.

18. Dulia Ortega D, Burns PN, Simpson DH, Wilson SR. Tissue Harmonic Imaging: Is It a Benefit for Bile Duct Sonography? AJR 2001; 176: 653-9.

19. Rosenthal SJ, Jones PH, Wetzel LH. Phase Inversion Tissue Harmonic Sonographic Imaging: A Clinical Utility Study. AJR 2001; 176: 1393-8.

20. Tranquart F, Grenier N, Eder V, Pourcelot L. Clinical use of ultrasound tissue harmonic imaging. Ultrasound Med Biol 1999; 25: 889-94.

21. Whittingham TA. Tissue harmonic imaging. Eur Radiol 1999; 9: 323-6. 
22. Berger A. What is fetal nuchal translucency? BMJ 1999; 318: 81.

23. Souka AP, Von Kaisenberg CS, Hyett JA, Sonek JD, Nicolaides KH. Increased nuchal translucency with normal karyotype. Am J Obstet Gynecol 2005; 192: 1005-21.

24. D'Alton ME, Goldman JC. Education and Quality Review for Nuchal Translucency Ultrasound. Semin Perinatol 2005; 29: 380-5.

25. Von Kaisenberg CS, Von Kaisenberg HK, Fritzer E, Schemm S, Heerlein IM, Jonat W. Fetal transabdominal anatomy scanning using standard views at 11 to 14 weeks' gestation.Am J Obstet Gynecol 2005; 192: 535-42.

26. Pasquini L, Tondi F, Rizzello F, Pontello V, Paoletti E and Fontanarosa M. Impact of tissue harmonic imaging on measurement of nuchal translucency thickness. Ultrasound Obstet Gynecol 2010; 36: 423-6. 